\title{
Perceived Quality of Life and Personality Traits of People Living with AIDS
}

\author{
Maria Tereza Andreola, PSYCHOL, MSc ${ }^{1}$, Cardine Reis, PT, PhD', Nair Fritzen dos Reis, PT, \\ $M S c^{2}$ and Rosemeri Maurici, MD, PhD ${ }^{2 *}$ \\ ${ }^{1}$ Health Science Master Degree Program, University of Southern Santa Catarina, Santa Catarina, Brazil \\ ${ }^{2}$ Postgraduate Program in Medical Sciences, Federal University of Santa Catarina, Santa Catarina, Brazil
}

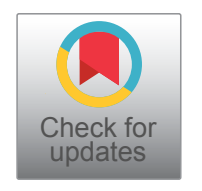

\begin{abstract}
Introduction: The increased survival rate of AIDS patients due to the advancements in the diagnosis and antiretroviral therapy, raised the interest in investigating quality of life (QOL) and the factors promoting psychological development of the patients, such as the way the individual sees its diagnosis. Therefore, this study aimed to assess association between QOL perception and personality traits of people living with AIDS.
\end{abstract}

Methods: A cross-sectional study with 80 subjects was conducted. The World Health Organization QOL Instrument of people living with HIV (abbreviated version) was used to characterize QOL, and the Battery Factor Personality for personality traits.

Results: Poor or low QOL perception and personality traits showed associations with neuroticism domain $(p=0.001)$, emotional instability facets $(p<0.001)$, and depression $(p<0.001)$. The results showed associations between poor or low QOL perception and low education level $(p=0.022)$, no occupation $(p=0.042)$, low CD4+T-cell count $(p=0.043)$ and detectable viral load $(p=0.016)$. Occupation $(p=0.028)$ and illicit drug use $(p=0.008)$ related to high neuroticism scores.

Conclusion: There was an association between poor or low QOL perception and personality traits expressing an emotional behavior model of the self-learned during early childhood. The prevalence of emotional instability and depression indicates the need for psychological care to treat the person as a whole, body and mind.

\section{Keywords}

AIDS, Quality of Life, Personality, Depression, Behavior

\section{Introduction}

After about 30 years of the first reports of the Acquired Immunodeficiency Syndrome (AIDS), epidemiological data reported that 38 million people were living with the Human Immunodeficiency Virus (HIV) in late 2019, and nearly 33 million have died of HIV-related causes [1]. Brazil has 920,000 AIDS cases reported in the last three decades. Santa Catarina is one of the Brazilian states with the highest prevalence, and Florianópolis ranks first among the Brazilian capitals, with a rate of 57 cases per 100,000 population [2].

Advancements in the diagnosis and antiretroviral therapy (ART) have brought important effects on patient survival $[3,4]$. In this sense, scientific studies have boosted interest in quality of life (QOL), such as the identification of factors promoting psychological development [5-7].

According to the World Health Organization (WHO), QOL is defined as "an individual's perception of their position in life in the context of the culture and value systems in which they live and in relation to their goals, expectations, standards and concerns" [8]. QOL is based on parameters related to individual's perception of their position in life (culture and value systems), the intensity in which ambition focuses on personal experience and relationship with their goals (expectations and standards) [5,9]. Studies of people living with HIV/AIDS indicate that the impact with the diagnosis, coping and control of the disease affect individual, cultural and social dimensions, interfering with QOL $[7,10-14]$.

*Corresponding author: Rosemeri Maurici, MD, PhD, Postgraduate Program in Medical Sciences, Federal University of Santa Catarina, Santa Catarina, Rodovia Virgílio Várzea, 2236, 601-A, Saco Grande, Florianópolis, SC, 88032-001, Brazil

Accepted: March 01, 2021

Published online: March 03, 2021

Citation: Andreola MT, Reis C, Reis NF, et al. (2021) Perceived Quality of Life and Personality Traits of People Living with AIDS. Arch Community Med 3(1):22-29 
Calman [9] defines QOL as the gap between expectations and achievements, emphasizing the importance of personal development. Personality and culture in which the individual is embedded are important factors in the "decision" to increase the achievements or decrease the expectations [5].

In the personality development process, which is constructed by people throughout their lives in interaction with the environment, the self is the categorical determinant $[15,16]$. Starting from their first and key relationships with the environment, the individuals learn and assimilate emotional and behavioral models which can turn permanent over time $[17,18]$. The way the individual sees the diagnosis depends on previous psychological dynamics, and this is driven by an affective-emotional character developed during childhood [19].

This study was intended to assess the association between QOL and personality traits of people living with AIDS.

\section{Methods}

\section{Design and setting of the study}

This cross-sectional study was conducted between August and December 2012, at the Nereu Ramos Hospital, which provides recognized expertise in pulmonology and infectious disease in the State of Santa Catarina, Brazil. The study was approved by the Human Research Ethics Committee of the University of Southern Santa Catarina (approval number 12.156.4.01.III). All patients provided written informed consent prior to enrollment in the study.

\section{Characteristics of participants}

Out of the total of 350 individuals diagnosed with AIDS, 80 consenting subjects aged over 18 years participated in the study. Those who presented severe cognitive impairment and illiterates would be excluded, but it didn't happen.

\section{Data Collection}

Data collection was conducted in a private room, preserving the privacy of the participants. The administration of data collection tools lasted about one hour.

The calibration of the two interviewers was performed by the researchers in a one-week period prior to the field investigation, consisting of theoretical review and adequacy of the tools and methods. A pilot study with 10 subjects was conducted, which was later included in the study sample.

The assessment of QOL was performed by using the World Health Organization Quality of Life-HIV Bref (WHOQOL-HIV Bref) validated in Brazil $[5,20]$. It includes six domain scores: Physical, psychological, level of independence, social relations, environment and spirituality/religiousness/personal beliefs [20]. The overall score of each domain, ranging between 4 and 20, it was calculated by using equations suggested by the WHO, which reflect the best and worst states of QOL [21]. The participants were categorized into three QOL domain score levels: Low, between 4 and 9.9; intermediate, between 10 and 14.9; and high, between 15 and 20 [22,23].

The Battery Factor Personality (BFP) is a psychometric instrument of personality assessment that identified the personality traits. It is based on the big five factors model of personality: Neuroticism, extraversion, agreeableness, consciousness and openness [14]. In order to interpret the results, the following score ranges by BFP were used: Very low (up to 14), low (15-29), medium (30-70), high (71-85) and very high (greater than 85 ). The low, very low and intermediate score ranges were named Group A, and the high and very high score ranges were named Group B [14].

The clinical, blood tests and demographic data were recorded on specific forms and were collected from medical records and participant information. The WHOQOL-HIV Bref and BFP were self-administered.

\section{Data Analysis}

The Excel ${ }^{\circledR}$ software was used to store the data, which was then exported to SPSS $21.0^{\circledR}$. Quantitative variables were summarized as minimum, maximum, mean and standard deviation. Nominal variables were summarized as absolute numbers and percentages. The association between QOL and personality traits was evaluated by using the chi-square test or Fisher's exact test, where appropriate. The association between neuroticism, QOL and numeric variables was evaluated by using the Student's t-test. For all the analyses, p-value of less than 0.05 were considered statistically significant.

\section{Results}

Of the surveyed subjects, $65 \%$ were male. Mean age was $46 \pm 8.8$ years, ranging from 22 years to 61 years. Most participants (33.8\%) had completed high school, and $57.5 \%$ were living without a steady partner. Out of the participants, $57.5 \%$ had no current occupation, being out of the labor market for $5.65 \pm 4.74$ years, in average, with a minimum of 1 year and a maximum of 16 years. Regarding the household income, $25 \%$ earned up to one minimum wage (BRL 678.00), and $75 \%$ earned more than a minimum wage.

The mean elapsed time since HIV diagnosis was $9.34 \pm$ 6.77 years, ranging from one year minimum and 32 years maximum. The median HIV viral load was $10,204 \pm 28,587$ copies. Viral load was undetectable in $76.2 \%$ of cases. Out of the participants, $65 \%$ reported the presence of comorbidities and, of these, $41.2 \%$ had hepatitis. With regard to drug abuse, $16.2 \%$ reported the use of illicit drugs, $18.8 \%$ stated that they were former drug users, and $65 \%$ reported that they did not do drugs.

QOL scores revealed that $5 \%$ were in the low level position, $55 \%$ were in the intermediate level position, and $40 \%$ were in the high level position. BFP questionnaire results revealed that $63.8 \%$ had high and very high scores in the Neuroticism factor, and $55 \%$ had low and very low scores in the Openness factor. A comparison between the BFP and QOL scores showed a significant relationship between poor or low perception of QOL and personality traits in the Neuroticism factor $(p=0.001)$, and in the facets of emotional instability ( $p$ $<0.001)$, depression $(p<0.001)$, communication $(p=0.002)$, dynamism $(p=0.010)$, and social interaction $(p=0.043)(\mathrm{Ta}-$ ble 1). 
Citation: Andreola MT, Reis C, Reis NF, et al. (2021) Perceived Quality of Life and Personality Traits of People Living with AIDS. Arch Community Med 3(1):22-29

Table 1: Distribution of BFP scores according to dichotomized QOL.

\begin{tabular}{|c|c|c|c|}
\hline \multicolumn{3}{|c|}{ Quality of Life } & \multirow[b]{2}{*}{$\mathbf{p}$} \\
\hline Battery Factor Personality & Low and Intermediate Level Position n(\%) & High Level Position n(\%) & \\
\hline \multicolumn{4}{|l|}{ Neuroticism } \\
\hline Group A* & $10(20.8)$ & $19(59.4)$ & 0.001 \\
\hline Group B* & $38(79.2)$ & $13(40.6)$ & \\
\hline \multicolumn{4}{|l|}{ Vulnerability } \\
\hline Group A & $18(37.5)$ & $18(56.3)$ & 0.099 \\
\hline Group B & $30(62.5)$ & $14(43.7)$ & \\
\hline \multicolumn{4}{|l|}{ Emotional instability } \\
\hline Group A & $11(22.9)$ & $22(68.7)$ & $<0.001$ \\
\hline Group B & $37(77.1)$ & $10(31.3)$ & \\
\hline \multicolumn{4}{|l|}{ Passivity/Lack of energy } \\
\hline Group A & $21(43.8)$ & $20(62.5)$ & 0.1 \\
\hline Group B & $27(56.2)$ & $12(37.5)$ & \\
\hline \multicolumn{4}{|l|}{ Depression } \\
\hline Group A & $5(10.4)$ & $20(62.5)$ & $<0.001$ \\
\hline Group B & $43(89.6)$ & $12(37.5)$ & \\
\hline \multicolumn{4}{|l|}{ Extraversion } \\
\hline Group A & $32(66.7)$ & $16(50.0)$ & \\
\hline Group B & $16(33.3)$ & $16(50.0)$ & 0.136 \\
\hline \multicolumn{4}{|l|}{ Communication } \\
\hline Group A & $42(87.5)$ & $18(56.3)$ & 0.002 \\
\hline Group B & $6(12.5)$ & $14(43.7)$ & \\
\hline \multicolumn{4}{|l|}{ Assertiveness } \\
\hline Group A & $28(58.3)$ & 23 (71.9) & 0.217 \\
\hline Group B & $20(41.7)$ & $9(28.1)$ & \\
\hline \multicolumn{4}{|l|}{ Dynamism } \\
\hline Group A & $32(66.7)$ & $12(37.5)$ & 0.01 \\
\hline Group B & $16(33.3)$ & $20(62.5)$ & \\
\hline \multicolumn{4}{|l|}{ Social interactions } \\
\hline Group A & $33(68.8)$ & 15 (46.9) & 0.043 \\
\hline Group B & $15(31.2)$ & 17 (53.1) & \\
\hline \multicolumn{4}{|l|}{ Socialization } \\
\hline Group A & 37 (77.1) & $22(68.8)$ & 0.407 \\
\hline Group B & $11(22.9)$ & $10(31.2)$ & \\
\hline \multicolumn{4}{|l|}{ Agreeableness } \\
\hline Group A & $18(37.5)$ & $13(40.6)$ & 0.779 \\
\hline Group B & $30(62.5)$ & 19 (59.4) & \\
\hline \multicolumn{4}{|l|}{ Tender-mindedness } \\
\hline Group A & $34(70.8)$ & $22(68.8)$ & 0.842 \\
\hline Group B & $14(29.2)$ & $10(31.2)$ & \\
\hline \multicolumn{4}{|l|}{ Trust in People } \\
\hline Group A & $42(87.5)$ & 25 (78.1) & 0.265 \\
\hline Group B & $6(12.5)$ & 7 (21.9) & \\
\hline
\end{tabular}


Citation: Andreola MT, Reis C, Reis NF, et al. (2021) Perceived Quality of Life and Personality Traits of People Living with AIDS. Arch Community Med 3(1):22-29

\begin{tabular}{|c|c|c|c|}
\hline $\begin{array}{r}\text { Achievement } \\
\text { Group A } \\
\text { Group B }\end{array}$ & $\begin{array}{l}34(70.8) \\
14(29.2)\end{array}$ & $\begin{array}{l}18(56.3) \\
14(43.7)\end{array}$ & 0.18 \\
\hline $\begin{array}{r}\text { Competence } \\
\text { Group A } \\
\text { Group B }\end{array}$ & $\begin{array}{l}35(72.9) \\
13(27.1)\end{array}$ & $\begin{array}{l}17(53.1) \\
15(46.9)\end{array}$ & 0.069 \\
\hline $\begin{array}{r}\text { Deliberation } \\
\text { Group A } \\
\text { Group B }\end{array}$ & $\begin{array}{l}37(77.1) \\
11(22.9)\end{array}$ & $\begin{array}{l}23(71.9) \\
9(28.1)\end{array}$ & 0.598 \\
\hline $\begin{array}{r}\text { Commitment } \\
\text { Group A } \\
\text { Group B }\end{array}$ & $\begin{array}{l}31(64.6) \\
17(35.4)\end{array}$ & $\begin{array}{l}20(62.5) \\
12(37.5)\end{array}$ & 0.849 \\
\hline $\begin{array}{l}\text { Openess } \\
\qquad \begin{array}{r}\text { Group A } \\
\text { Group B }\end{array}\end{array}$ & $\begin{array}{l}42(87.5) \\
6(12.5)\end{array}$ & $\begin{array}{l}26(81.3) \\
6(18.7)\end{array}$ & 0.443 \\
\hline $\begin{array}{l}\text { Openess to experience } \\
\text { Group A } \\
\text { Group B }\end{array}$ & $\begin{array}{l}42(87.5) \\
6(12.5)\end{array}$ & $\begin{array}{l}26(81.3) \\
6(18.7)\end{array}$ & 0.443 \\
\hline $\begin{array}{l}\text { Liberalism } \\
\qquad \begin{array}{r}\text { Group A } \\
\text { Group B }\end{array}\end{array}$ & $\begin{array}{l}33(68.8) \\
15(31.2)\end{array}$ & $\begin{array}{l}23 \text { (71.9) } \\
9(28.1)\end{array}$ & 0.765 \\
\hline $\begin{array}{c}\text { Novelty-seeking } \\
\text { Group A } \\
\text { Group B }\end{array}$ & $\begin{array}{l}42(87.5) \\
6(12.5)\end{array}$ & $\begin{array}{l}27(84.4) \\
5(15.6)\end{array}$ & 0.747 \\
\hline
\end{tabular}

*Group A (low, very low and intermediate).

${ }^{* *}$ Group B (high and very high).

Table 2: Distribution of the clinical, blood tests and sociodemographic variables according to dichotomized QOL and the Neuroticism domain.

\begin{tabular}{|c|c|c|c|c|c|c|}
\hline \multirow[b]{2}{*}{ Variables } & \multicolumn{3}{|l|}{ Quality of Life } & \multicolumn{3}{|l|}{ Neuroticism } \\
\hline & $\begin{array}{l}\text { Low and Intermediate } \\
\text { Level Positions n (\%) }\end{array}$ & $\begin{array}{l}\text { High Level } \\
\text { Position n (\%) }\end{array}$ & $\mathbf{p}$ & $\begin{array}{l}\text { Low, Very Low and } \\
\text { Intermediate } \mathrm{n}(\%)\end{array}$ & $\begin{array}{l}\text { High and } \\
\text { Very High n } \\
(\%)\end{array}$ & $\mathbf{p}$ \\
\hline $\begin{array}{l}\text { Gender } \\
\qquad \begin{array}{c}\text { Female } \\
\text { Male }\end{array}\end{array}$ & $\begin{array}{l}19(39.6) \\
29(60.4)\end{array}$ & $\begin{array}{l}9(28.1) \\
23(71.9)\end{array}$ & 0.293 & $\begin{array}{l}10(34.5) \\
19(65.5)\end{array}$ & $\begin{array}{l}18(35.3) \\
33(64.7)\end{array}$ & 0.942 \\
\hline $\begin{array}{l}\text { Relationship } \\
\text { With a steady partner } \\
\text { Without a steady partner }\end{array}$ & $\begin{array}{l}18(37.5) \\
30(62.5)\end{array}$ & $\begin{array}{l}16(50.0) \\
16(50.0)\end{array}$ & 0.268 & $\begin{array}{l}13(44.8) \\
16(55.2)\end{array}$ & $\begin{array}{l}21(41.2) \\
30(58.8)\end{array}$ & 0.751 \\
\hline $\begin{array}{l}\text { Education level } \\
\qquad \begin{array}{l}\text { Category } 1^{*} \\
\text { Category } 2^{* *}\end{array}\end{array}$ & $\begin{array}{l}29(60.4) \\
19(39.6)\end{array}$ & $\begin{array}{l}11 \text { (34.4) } \\
21(65.6)\end{array}$ & 0.022 & $\begin{array}{l}11 \text { (37.9) } \\
18(62.1)\end{array}$ & $\begin{array}{l}29(56.9) \\
22(43.1)\end{array}$ & 0.104 \\
\hline $\begin{array}{c}\text { Occupation } \\
\text { Yes } \\
\text { No }\end{array}$ & $\begin{array}{l}32(66.7) \\
16(33.3)\end{array}$ & $\begin{array}{l}14(43.8) \\
18(56.2)\end{array}$ & 0.042 & $\begin{array}{l}12(41.4) \\
17(58.6)\end{array}$ & $\begin{array}{l}34 \text { (66.7) } \\
17(33.3)\end{array}$ & 0.028 \\
\hline Length of withdrawal from work & $4.8 \pm 4.4$ & $7.6 \pm 5.2$ & 0.069 & $5.1 \pm 4.0$ & $5.9 \pm 5.0$ & 0.634 \\
\hline $\begin{array}{l}\text { Household income } \\
>1 \mathrm{MW}^{* * *} \\
\text { Up to } 1 \mathrm{MW}\end{array}$ & $\begin{array}{l}33(68.8) \\
15(31.2)\end{array}$ & $\begin{array}{l}27(84.4) \\
5(15.6)\end{array}$ & 0.114 & $\begin{array}{l}24(82.8) \\
5(17.2)\end{array}$ & $\begin{array}{l}36(70.6) \\
15(29.4)\end{array}$ & 0.227 \\
\hline
\end{tabular}


Citation: Andreola MT, Reis C, Reis NF, et al. (2021) Perceived Quality of Life and Personality Traits of People Living with AIDS. Arch Community Med 3(1):22-29

\begin{tabular}{|c|c|c|c|c|c|c|}
\hline $\begin{array}{l}\text { Time elapsed since HIV } \\
\text { diagnosis" }\end{array}$ & $8.1 \pm 6.2$ & $11.3 \pm 7.3$ & 0.038 & $9.6 \pm 5.4$ & $9.2 \pm 7.5$ & 0.806 \\
\hline $\begin{array}{l}\text { Viral load } \\
\qquad \begin{array}{l}\text { Detectable } \\
\text { Undetectable }\end{array}\end{array}$ & $\begin{array}{l}16(33.3) \\
32(66.7)\end{array}$ & $\begin{array}{l}3(9.4) \\
29(90.6)\end{array}$ & 0.016 & $\begin{array}{l}6(20.6) \\
23(79.3)\end{array}$ & $\begin{array}{l}13(25.4) \\
38(74.5)\end{array}$ & 0.628 \\
\hline $\begin{array}{l}\text { CD4+ T-Cell Count } \\
<200 \text { cells } / \mathrm{mm}^{3} \\
\geq 200 \text { cells } / \mathrm{mm}^{3}\end{array}$ & $\begin{array}{l}10(20.8) \\
38(79.2)\end{array}$ & $\begin{array}{l}1(3.1) \\
31(96.9)\end{array}$ & 0.043 & $\begin{array}{l}2(6.9) \\
27(93.1)\end{array}$ & $\begin{array}{l}9(17.6) \\
42(82.4)\end{array}$ & 0.311 \\
\hline $\begin{array}{l}\text { Illicit Drug Use } \\
\begin{array}{l}\text { Former User } \\
\text { No } \\
\text { Yes }\end{array}\end{array}$ & $\begin{array}{l}11(22.9) \\
28(58.3) \\
9(18.8)\end{array}$ & $\begin{array}{l}4(12.5) \\
24(75.0) \\
4(12.5)\end{array}$ & 0.302 & $\begin{array}{l}5(17.2) \\
24(82.8) \\
-\end{array}$ & $\begin{array}{l}10(19.6) \\
28(54.9) \\
13(25.5)\end{array}$ & 0.008 \\
\hline $\begin{array}{l}\text { Comorbidity } \\
\qquad \begin{array}{c}\text { No } \\
\text { Yes }\end{array}\end{array}$ & $\begin{array}{l}15(31.3) \\
33(68.7)\end{array}$ & $\begin{array}{l}13(40.6) \\
19(59.4)\end{array}$ & 0.389 & $\begin{array}{l}11 \text { (37.9) } \\
18(62.1)\end{array}$ & $\begin{array}{l}17(33.3) \\
34(66.7)\end{array}$ & 0.679 \\
\hline $\begin{array}{l}\text { Hepatitis } \\
\qquad \begin{array}{r}\text { No } \\
\text { Yes }\end{array}\end{array}$ & $\begin{array}{l}28(58.3) \\
20(41.7)\end{array}$ & $\begin{array}{l}19(59.4) \\
13(40.6)\end{array}$ & 0.926 & $\begin{array}{l}15(51.7) \\
14(48.3)\end{array}$ & $\begin{array}{l}32(62.7) \\
19(37.3)\end{array}$ & 0.336 \\
\hline
\end{tabular}

*Category 1 (complete or incomplete Primary School and incomplete Secondary School)

${ }^{* *}$ Category 2 (Secondary School and College Degree or incomplete Higher Education)

\#Mean \pm Standard Deviation

${ }^{* * *}$ Minimum Wage (BRL 678.00).

With regard to clinical, blood tests and sociodemographic variables according to the dichotomized QOL items and dichotomized Neuroticism dimensions, association was found between poor or low perceived QOL and low educational level $(p=0.022)$, no occupation $(p=0.042)$, low CD4+ T-cell count $(p=0.043)$, and detectable viral load $(p=0.016)$. In addition, it was found association between high scores in the Neuroticism factor and variables such as no occupation $(p=$ $0.028)$ and drug abuse $(p=0.008)$ (Table 2$)$.

\section{Discussion}

The findings of this study showed that the perceived QOL of people living with AIDS was prevalent in the intermediate level position. In analyzing the stages of HIV infection, Fleck [5] described that the WHOQOL-HIV scores decreased among HIV-infected people as the disease progressed, having even lower scores in the AIDS stage, associated with poorer QOL than their counterparts.

A significant association was found between QOL and education level. The data showed that less educated people tend to have poorer or lower perception of QOL than highly educated people, as reported by the literature [22-24]. Meneghetti [17] points out that people acquire a system of evaluation, of how to perceive themselves and the world in early learning stages. Consequently, subjects may develop the resources they need to cope with life and its obstacles throughout their life.

The variable "no occupation" was significantly associated with poor or low perception of QOL and had a high score in the Neuroticism factor. These findings corroborate those found by Gaspar, et al. [25] and Ferreira, Oliveira and Paniago
[22] who observed that subjects who worked had higher QOL scores than those who had no occupation. Studies $[26,27]$ suggest that a seropositive status directly affects the QOL of people living with HIV when they are on a leave of absence due to their health condition, since work provides them with a sense of existential meaning within society. Work generates financial benefits, besides providing a person with assistance and collective support, and a sense of usefulness, thus allowing ease the stress caused by the disease and stimulating psychological health and good social relations $[25,28]$.

With regard to personality traits, the surveyed subjects with no occupation had a high level of neuroticism. The Neuroticism factor is associated with chronic level adjustment and emotional instability of individuals, reflecting a cognitive and behavioral lifestyle that may present difficulty to use adaptive and coping strategies in conflict situations [14]. Having a labor activity is important to cope with HIV-seropositive status, since occupation provides the subjects with responsibility, sense of usefulness and extension of social relations, besides keeping their mind occupied and avoiding thinking about the disease. The side effects of HAART treatment often require adjustments at work. Consequently, withdrawal and leave of absence are quite common in these cases [29]. Work is a key element in shaping the social and psychological identity of individuals, making it possible to discover and develop their skills [29]. It could be said that work provides financial resources and autonomy, builds self-esteem, and is the principle of freedom of the human being [17].

In this study, findings revealed that low CD4+ T-cell count and detectable viral load were associated with poor or low perceived QOL. Other studies have also identified that CD4+ 
T-cell count and viral load were associated with QOL [3032]. Ferreira, Oliveira and Paniago [22] found a significant relationship between them and the level of independence domain of QOL. Low CD4+ T-cell counts and high viral load compromise the immune system, and predispose to disease symptoms, opportunistic infections and related adverse reactions of drugs that negatively affect QOL and survival of these subjects $[22,33,34]$. Therefore, it is possible to verify that the physical health status may interfere with the way participants perceive QOL.

The findings showed a significant association with the use of illicit drugs and the Neuroticism factor. Similar data were found by Mohan and Bedi [35] who concluded that the Neuroticism factor is associated with drug abuse in people living with HIV/AIDS, and is related to risk behaviors. Individuals with high Neuroticism scores are more likely to experience feelings such as depression, anger, guilt and anxiety than the average for the general population. This combination of feelings can provide vulnerability to risk behaviors. Serafini and Bandeira [13] have also studied young people living with HIV and their relationship with Neuroticism. They stress that characteristics such as risk behavior, perceived by the high scores in the psychosocial disturbance factor, have acted as a factor of exposure to infection.

Analyzing the association between QOL and BFP, a significant relationship was found in the Neuroticism factor, expressing scores above average in this personality trait, leading to a poor or low perception of QOL. Neuroticism relates to individual differences and expresses how individuals experience negative emotions (grief, anguish, suffering, among others), and cognitive and behavioral lifestyles that emerge from these experiences. They present difficulty tolerating frustration caused by unfulfilled desires $[12,14,36]$.

Penedo, et al. [37] studied the relationship between personality traits and QOL in people living with HIV, and identified that high scores on the Neuroticism factor were significantly associated with poor or low perception of QOL. With regard to the role of personality and QOL in people living with HIV, the results showed that Neuroticism was associated with poor or low perception of QOL among men who have sex with men and injecting drug users [38].

In a study conducted in Brazil with young people living with HIV, findings revealed high levels of Neuroticism, in particular regarding the depression facet, such as the feeling of loneliness, low expectations about the future and lack of goals in life [13]. In this study, the Neuroticism factor was shown to be significantly associated with the emotional instability and depression facets. The emotional instability facet reveals characteristics of mood swings and difficulty controlling negative emotions, tending to make hasty decisions quite often, besides having low tolerance to frustration $[12,14]$. The depression facet assesses the standards of interpretation that people have in relation to the events that occur in their lives. Individuals with high scores on this facet tend to report feelings of pessimism, monotonous and unexciting life, loneliness and lack of goals or negative expectations about the future, considering themselves unable to cope with everyday difficulties [14].
A search conducted by Serafini and Bandeira [13] found high levels of Neuroticism in the depression facet. According to Castanha, et al. [26] AIDS is anchored in psych affective diseases, depression being considered a key element associated with the disease, due to the high scores in this facet observed in people living with HIV. There is significant evidence in the literature that depression symptoms interfere with psychophysical functioning, affecting multiple domains of QOL assessment. The state of depression is considered one of the strongest predictors of poor QOL in people living with HIV [5].

This finding corroborates the understanding that depression is prior to infection in people living with HIV/AIDS, which is resulting from the personality structure of the individuals and the environment in which they live [39]. According to Meneghetti [17], depression has an important role because it precedes chronic diseases. According to this author, depression is the deprivation of an instinct that has not been identified, approved and lived in its legitimate value as a life instinct. Therefore, it is a vital basic impulse that was blocked. There is not the lack of energy, it is exactly the opposite. The person feels energy, but does not know how to express it formally, and therefore, this feeling consumes, afflicts and sickens the subject. In this sense, this instinct deprivation is due to an upbringing that did not consent to the development and exposure of primary instincts such as aggression, sexuality, individuality and pride. The loss of balance to give flow to the instincts may result in depressive states over the years.

The emotional, cognitive and behavioral aspects regarding the state of emotional instability and depression are dimensions that influence the perception of QOL. Despite not having used a specific instrument to identify symptoms of depression in this study, the data suggest that the participants tended to use passive coping strategies, rather than using more strategies that are active in adverse situations, which was also due to a more pessimistic perception.

On Extraversion domain, low scores on communication and social interactions tended towards an association with a poor or low perception level of QOL. Studies regarding the psychosocial aspects (prejudice, segregation and stigma) in people living with HIV/AIDS stress that they can influence and guide the conduct of these people $[18,25,40]$. Isolation is common, arising from the fear of social prejudice $[17,26]$. Furthermore, this self-exile can be interpreted as an attitude of escape from social living in order to forget their health condition $[41,42]$. In the face of social exclusion, the person may use defensive strategies, based on the fear of death [40], or rejection [17], thus resulting in social death [42].

The high scores in the Neuroticism domain indicate a tendency towards shyness, passivity, and social isolation, and are related to how people copy with social exclusion. These psychological attitudes are related to external situations (social prejudice), as well as endogenous situations (personality traits), which directly interfere with people's perception of $\mathrm{QOL}$, in the way they perceive themselves and relate to the surrounding world. Social exclusion may result in the impoverishment of social relations, including distrust, hostility, as well as depressive, anxious and confused attitudes. 
The high scores of the surveyed subjects in the Neuroticism domain reveal a dimension of personality that refers to a chronic condition of irritability, tending to interact improperly in the social relationships, in a rigid or constricted way $[14,43]$. This state represents a tensed self, which interferes with the willpower and action in response to internal and external stimuli.

According to França [40] and Souto [18] people living with HIV/AIDS often tend to build self-prejudice concept, expressing a victim mentality, blaming the group for social exclusion, which indicates a mental structure in an attempt to justify a person's relationship with himself, establishing behavioral and cognitive structures in order to adapt to the condition that the disease situation requires. The behavioral attitudes, according the authors can be expressed through irreverence, religiosity, challenge traditions, the right to pity, as well as feigned indifference. People living with chronic diseases, especially AIDS, alcohol and substance abuse, generally state that they are in this situation through no fault of their own, but rather of society, traders, institutions, and families $[17,18,44]$.

With regard to HIV infection and personality traits, Ader, Cohen and Felten [45] raise some ticklish questions: Why can the social environment determine the individual response to infectious disease? Why do latent viruses give rise to disease manifested under stressful circumstances for the infected organism? Or why, when exposed to the same infectious agents, only some individuals get sick? Ulla and Remor [46] conclude that the relationship between psychological factors and immune changes that would lead to a condition more susceptible to pathogens are crucial for people living with HIV, because it would trigger a faster viral progression. AIDS is associated with lifestyle, according to Meneghetti [19].

\section{Conclusions}

Considering that QOL perception is expressed in terms of satisfaction, happiness and achievement striving, it can be inferred that to improve health-related QOL perception it is important to stimulate the need to reduce the gap between expectations and achievements. The internal aspects that relate to personality are fundamental factors to be evaluated and, consequently, the lifestyle of people living with AIDS as well.

The findings of this study demonstrated that there was a significant association between perceived QOL and personality traits of people living with AIDS. This association was evident in relation to the high scores in the Neuroticism domain, out of which the state of emotional instability and depression significantly interfere with poor or low QOL perception.

The prevalence of emotional instability and depression indicates the need for psychological care. Psychotherapeutic counseling could provide people with a re-assessment of personality structures that characterize their lifestyle. More humane and effective medical care is required to treat the person as a whole, body and mind.

\section{Conflict of Interests}

The author(s) declare no potential conflicts of interest with respect to the research, authorship, and/or publication of this article.

\section{Funding}

The author(s) received no financial support for the research, authorship, and/or publication of this article.

\section{References}

1. https://www.unaids.org/en/resources/fact-sheet

2. http://www.aids.gov.br/pt-br/pub/2019/boletim-epidemiologico-de-hivaids-2019

3. Marins JRP, Jamal LF, Chen SY, et al. (2003) Dramatic improvement in survival among adult Brazilian AIDS patients. AIDS 17: 1675-1682.

4. Wu AW (2000) Quality of life assessment comes of age in the era of highly active antiretroviral therapy. AIDS 14: 1449-1451.

5. Fleck MPA (2008) A avaliação da qualidade de vida: Guia para profissionais da saúde. Porto Alegre: Artmed, 228.

6. Panzini RG, Rocha NS, Bandeira DR, et al. (2007) Qualidade de vida e espiritualidade. Arch Clin Psychiatry (São Paulo) 34: 105-115.

7. Seidl EMF, Zannon CML, Tróccoli BT (2005) Pessoas vivendo com HIV/AIDS: Enfrentamento, suporte social e qualidade de vida. Psicol Reflexão e Crítica 18: 188-195.

8. (1993) Study protocol for the World Health Organization project to develop a quality of life assessment instrument (WHOQOL). Qual Life Res 2: 153-159.

9. Calman KC (1984) Quality of life in cancer patients--an hypothesis. J Med Ethics 10: 124-127.

10. Geocze L, Mucci S, Marco DMA, et al. (2010) Qualidade de vida e adesão ao tratamento anti-retroviral de pacientes portadores de HIV. Rev Saude Publica 44: 743-749.

11. Reis RK, Haas VJ, Santos CBD, et al. (2011) Symptoms of depression and quality of life of people living with HIV/AIDS. Rev Lat Am Enfermagem 19: 874-881.

12. Nunes CH, Hutz CS, Giacomoni CH (2009) Associação entre bem estar subjetivo e personalidade no modelo dos cinco grandes fatores. Avaliação Psicológica 8: 99-108.

13. Serafini AJ, Bandeira DR (2009) Jovens vivendo com HIV/AIDS: A influência da rede de relações, do coping e do neuroticismo sobre a satisfação de vida. Rev Psiquiatr do Rio Gd do Sul 31: 51-59.

14. Nunes CHSS, Hutz CS, Nunes MFO (2010) Battery factor personality (BFP): Handbook. ( $1^{\text {st }}$ edn), Casa do Psicólogo, São Paulo.

15. Meneghetti A (2004) Ontopsychology handbook. Psicologica Editrice, Rome.

16. Meneghetti A (1999) La nascita dell'io. Psicologica Editrice, Rome.

17. Meneghetti A (2006) Cliical ontopsychology. Psicologica Editrice, Rome.

18. Souto BGA (2008) Psycho-social reflections around the HIV infected person. J Brazilian Soc Intern Med 6: 115-122.

19. Meneghetti A (2008) La psicosomatica nell'ottica ontopsicologica. Psicologica Editrice, Rome.

20. Zimpel RR, Fleck MP (2007) Quality of life in HIV-positive Brazilians: Application and validation of the WHOQOL-HIV, Brazilian version. AIDS Care 19: 923-930. 
21. Fleck MP, Louzada S, Xavier M, et al. (2000) Aplicação da versão em português do instrumento abreviado de avaliação da qualidade de vida "WHOQOL-bref." Rev Saude Publica 34: 178-183.

22. Ferreira BE, Oliveira IM, Paniago AMM (2012) Qualidade de vida de portadores de HIV/AIDS e sua relação com linfócitos CD4+, carga viral e tempo de diagnóstico. Rev Bras Epidemiol 15: 7584.

23. Santos ECMD, França JI, Lopes F (2007) Qualidade de vida de pessoas vivendo com HIV/Aids em São Paulo. Rev Saude Publica 41: 64-71.

24. Silva JD, Bunn K, Bertoni RF, et al. (2013) Quality of life of people living with HIV. AIDS Care 25: 71-76.

25. Gaspar J, Reis RK, Pereira FMV, et al. (2011) Qualidade de vida de mulheres vivendo com o HIV/aids de um município do interior paulista. Rev Esc Enferm USP 45: 230-236.

26. Castanha AR, Coutinho MDPDL, Saldanha AAW, et al. (2006) Aspectos psicossociais da vivência da soropositividade ao HIV nos dias atuais. Psico 37: 47-56.

27. Castanha AR, Coutinho MDPDL, Saldanha AAW, et al. (2007) Avaliação da qualidade de vida em soropositivos para o HIV. Estud Psicol 24: 23-31.

28. Rüütel K, Pisarev H, Loit HM, et al. (2009) Factors influencing quality of life of people living with HIV in Estonia: A cross-sectional survey. J Int AIDS Soc 16: 12-13.

29. Ferreira RCM, Figueiredo MADC, Souza LB (2011) Tabalho, HIV/ AIDS: Enfrentamento e dificuldades relatadas por mulheres. Psicol em Estud 16: 259-267.

30. Call SA, Klapow JC, Stewart KE, et al. (2000) Health-related quality of life and virologic outcomes in an HIV clinic. Qual Life Res 9: $977-985$

31. Gill CJ, Griffith JL, Jacobson D, et al. (2002) Relationship of HIV viral loads, CD4 counts, and HAART use to health-related quality of life. J Acquir Immune Defic Syndr 30: 485-492.

32. Hsiung PC, Fang CT, Chang YY, et al. (2005) Comparison of WHOQOL-BREF and SF-36 in patients with HIV infection. Qual Life Res 14: 141-150.

33. Acurcio FDA, Guimarães MDC (1996) Acessibilidade de indivíduos infectados pelo HIV aos serviços de saúde: uma revisão de literatura. Cad Saude Publica 12: 233-242.
34. Gabriel R, Barbosa DA, Vianna LAC (2005) Perfil epidemiológico dos clientes com HIV/AIDS da unidade ambulatorial de hospital escola de grande porte: município de São Paulo. Rev Lat Am Enfermagem 13: 509-513.

35. Mohan V, Bedi S (2010) Extraversion, neuroticism, anger and self-esteem of HIV positive youth. J Behav Sci 5: 60-74.

36. McCrae RR, John OP (1992) An introduction to the five-factor model and its applications. J Pers 60: 175-215.

37. Penedo FJ, Gonzalez JS, Dahn JR, et al. (2003) Personality, quality of life and HAART adherence among men and women living with HIV/AIDS. J Psychosom Res 54: 271-278.

38. Burgess AP, Carretero M, Elkington A, et al. (2000) The role of personality, coping style and social support in health-related quality of life in HIV infection. Qual Life Res 4: 423-437.

39. Filho NS, Souza LDRD (2004) Associação entre o diagnóstico adaptativo, indicadores de evolução clínica e o teste de relações objetais em pacientes com infecção pelo HIV-1, doentes ou não. Psicologia, Saúde \& Doenças 5: 195-213.

40. França ISXD (2000) Con-vivendo com a soropositividade HIV/ AIDS: Do conceito aos preconceitos. Rev Bras Enferm 53: 491498.

41. Lopes MVDO, Fraga MDNO (1998) Pessoas vivendo com HIV: Estresse e suas formas de enfrentamento. Rev Lat Am Enfermagem 6: 75-81.

42. Seben G, Gauer GJC, Giovelli GRM, et al. (2008) Adultos jovens portadores de HIV: Análise dos processos subjetivos no enfrentamento da doença. Psic Rev da Vetor Ed 9: 63-72.

43. Costa PT, McCrae RR (1987) Neuroticism, somatic complaints, and disease: Is the bark worse than the bite? J Pers 55: 299-316.

44. Meneghetti A (2010) The psychosomatics of cancer. J Chinese Clin Med 5: 371-387.

45. Ader R, Cohen N, Felten DL (1987) Brain, behavior, and immunity. Brain Behav Immun 1: 1-6.

46. Ulla S, Remor EA (2002) Psiconeuroimunologia e infecção por HIV: Realidade ou ficção? Psicol Reflexão e Crítica 15: 113-119.

DOI: $10.36959 / 547 / 646$

Copyright: (C) 2021 Andreola MT, et al. This is an open-access article distributed under the terms of the Creative Commons Attribution License, which permits unrestricted use, distribution, and reproduction in any medium, provided the original author and source are credited. 